\title{
UTCI BASED ASSESSMENT OF URBAN OUTDOOR THERMAL COMFORT IN BELGRADE, SERBIA
}

\author{
Milica Lukići*, \\ Jelena Milovanović ${ }^{2}$ \\ 1 University of Belgrade - \\ Faculty of Geography, \\ Belgrade, Serbia \\ ${ }^{2}$ Study program Environment and \\ Sustainable Development, \\ Singidunum University, \\ Belgrade, Serbia
}

\begin{abstract}
:
The main purpose of this research is to assess the outdoor thermal comfort (OTC) of Belgrade, in order to investigate how distinct bioclimatic conditions influence on the human organism during the summer in urban environments. Universal Thermal Climate Index, which represents the heat stress of the human organism caused by meteorological conditions, was used as an indicator of thermal comfort in the study. The main goal was to monitor changes in the index values, as well as the frequency of various categories of thermal stress during the hottest part of the year (months June, July, and August). For this research, mean daily meteorological data from the Meteorological Observatory Belgrade have been collected for the period from 1999 to 2018. The obtained results show a gradual change in the bioclimatic conditions, which are generally more adverse in July and August. Results also indicate that OTC in Belgrade was considerably reduced, especially in 2007, 2012, 2015,2017 , and 2018 .
\end{abstract}

Keywords:

UTCI, outdoor thermal comfort, urban environments, Belgrade .

\section{INTRODUCTION}

Extreme weather conditions are one of the most common consequences of climate change, as a global threat [1]. It is followed by the severe biometeorological conditions that can have a strong impact on public health and quality of life in urban areas. In addition, it has a serious impact on thermal comfort (which can be outdoor or indoor). The generally accepted definition of thermal comfort is: "it is the condition of mind that expresses satisfaction with the thermal environment and is assessed by subjective evaluation" [2].

Findings of Geletič et al. [3,4] have shown that in Central Europe and other European regions, heat-related hazards such as extreme temperatures, heatwaves, tropical days and nights will become more frequent during the 21 st century. Cities, as the areas where the increase in population density is pronounced and in which a larger amount of heat accumulates due to various anthropogenic factors, are prone to the emergence 
of urban heat islands (UHI) and heat-related hazards [4]. That is the main reason why the issue of outdoor thermal comfort (OTC) in urban areas has become the subject of numerous studies. Among currently conducted studies and applied indices, the Universal Thermal Climate Index (UTCI) is increasingly popular [1]. UTCI is claimed to be a universal thermal index that can be successfully applied in the evaluation of open spaces in different geographical areas [5]. According to Binarti et al. [6] the UTCI multi-node model is very precise "in replicating the human dynamic thermal response under a wide range of thermal environments".

OTC in urban environments, its perception, and its varieties due to different climate zones fascinate and attract many authors worldwide, and as a consequence significant improvement was made and achievements were noticed in this science field after the year 2000 [7]. The application of UTCI for this purpose is very common. Kolendowicz et al. [8] have applied this index in order to evaluate bioclimatic conditions in the area of the southern Baltic coast, for the period 1981-2014. Lam and Lau [7] have examined the divergence in thermal perception and way of dressing between inhabitants from two different climate regions (Melbourne and Hong Kong) over similar UTCI ranges in summer. Bröde et al. $[9,10]$ have applied this index to assess the outdoor urban thermal comfort of the city of Curitiba (Southern Brazil). Abdel-Ghany et al. [11] have studied different thermal indices (among them UTCI) to assess the arid environment of the central region of Riyadh, Saudi Arabia. In a study conducted by Mölders [12], hourly UTCI values were determined, based on meteorological data from 456 stations in Alaska, eastern Russia, and northwestern Canada over a period of 38 years (1979-2017). The UTCI based assessment of bioclimatic conditions of urban areas in Europe has been the subject of numerous research papers and projects so far $[1,6,13,14,15,16]$. In recent years, urban OTC in Western Balkan countries was investigated in several studies, and its perception in many cases was evaluated through UTCI $[15,17,18,19,20]$.

This scientific field is in a phase of accelerated development, because of the increasing consequences of climate change, the negative effect of global warming, and the worsening of living conditions in big cities. As Pantavou et al. [16] have mentioned, the estimation of urban thermal comfort is pivotal in the foundation of efficient health warning systems and planning public spaces in cities.

\section{STUDY AREA}

Belgrade, the capital and largest city of Serbia, is located on the Balkan Peninsula in Southeast Europe. Geographically, it lies on the Sava and Danube river bank (Fig. 1), near the Mountain Avala $(511 \mathrm{~m}$ ) and it belongs to a continental climate region. Summers are warm and maximum temperatures are most commonly recorded during July and August, while the minimum temperatures are most commonly recorded in January [21]. Belgrade's climate is considered to be a Cfa type (a humid subtropical type of climate) according to the Köppen-Geiger climate classification. An average annual temperature observed in the city for the period from 2000 to 2017 was $13.4^{\circ} \mathrm{C}$ [22]. The increase in daily temperature in Belgrade is evident, and it is additionally influenced by the existence of an urban heat island [17].

According to the Statistical Office of the Republic of Serbia [23], the city municipality of Vračar, which covers an area of just $3 \mathrm{~km}^{2}$, is the most densely populated part of Belgrade, with 19285 inhabitants $/ \mathrm{km}^{2}$ (in total 57856 dwellers in 2019). It is also a highly urbanized zone, characterized by a lack of open green spaces (Fig. 2). Placed in this environment, the meteorological station Meteorological Observatory Belgrade (western Vračar, $44^{\circ} 48^{\prime} \mathrm{N}, 20^{\circ} 28^{\prime} \mathrm{E}, 132 \mathrm{~m}$ ) gives us meteorological data which best reflects the bioclimatic conditions that occur in the central urban areas [19].

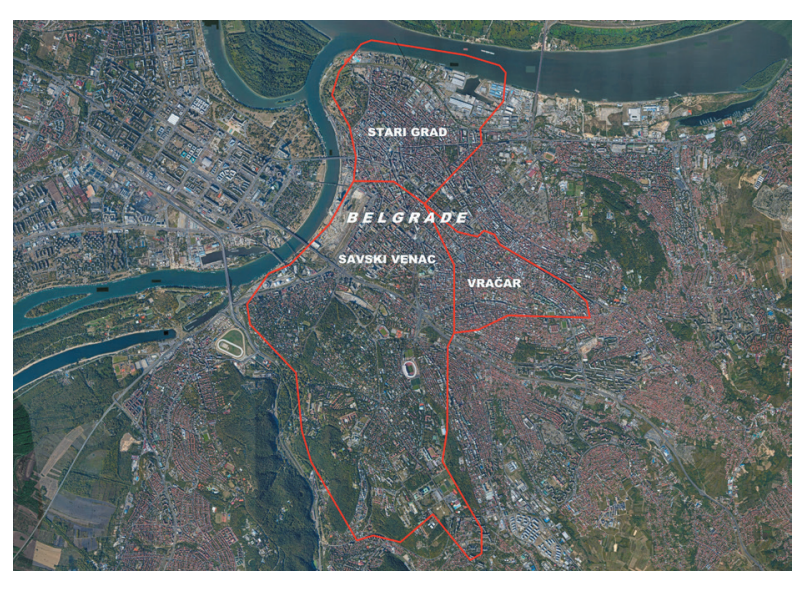

Fig.1. Central urban zone of Belgrade - City municipalities Vračar, Stari grad and Savski venac 


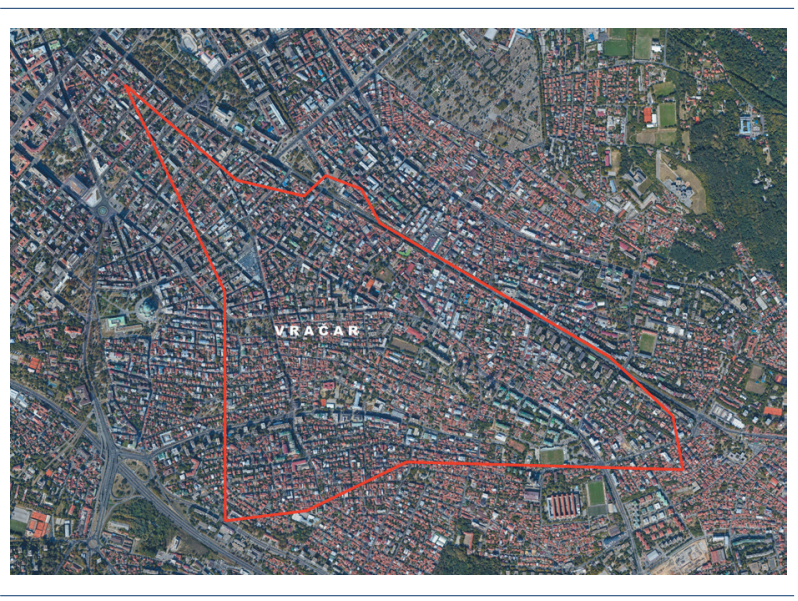

Fig. 2. The city municipality of Vračar

One of the most significant results of scientific cooperation within the "European COST Action 730" network is the presentation of the Universal Thermal Climate Index, which has significantly improved human biometeorology as a science [10]. The advantages of this index were also recognized by the World Meteorological Organization (WMO) [8]. Since then, the application of the UTCI has become increasingly common, both in scientific and epidemiological researches and in fields such as the development of health warning systems, urban and spatial planning, etc. Thanks to that, this index is slowly gaining the status of "an internationally standardized instrument for the assessment of thermal environments" [24].

The UTCI $\left({ }^{\circ} \mathrm{C}\right)$ combines both meteorological and physiological parameters for the determination of thermal comfort through the evaluation of human energy balance [25]. All physiological parameters used in this study were determined and defined by international standards and previously conducted scientific tests. As for the physiological parameters, they refer primarily to the metabolic processes in the human body. This kind of process produces heat in the organism that is continuously exchanged with the immediate surroundings. By virtue of this capability, the human body manages to maintain constant body temperature [13,14,17,18,24,25].

According to the ANSI/ASHRAE Standard 55 [2,18] "MET" is defined "as a measure of physical activity and it corresponds to the release of human heat of $58.2 \mathrm{~W} . \mathrm{m}^{-2}$ from an average skin surface area of an adult $\left(1.8 \mathrm{~m}^{2}\right)$, i.e. it is equivalent to the energy rate generated per unit surface area of an average person at rest. Further, ISO 8996 [26] has defined the standardized value of the metabolic heat energy $(\mathrm{M})$ which amounts to $135 \mathrm{~W} \cdot \mathrm{m}^{-2}(2.3 \mathrm{MET})$, for a person moving at a speed of $1.1 \mathrm{~m} . \mathrm{s}^{-1}\left(4 \mathrm{~km} \cdot \mathrm{h}^{-1}\right)$.
In this research, the UTCI-Fiala multi-node model of human thermoregulation integrated with an adaptive clothing model was used for the simulation of the human reaction [18,27]. UTCI can most easily be explained as "the air temperature of the reference environment which produces an equivalent dynamic physiological response under a set of reference conditions “ $[9,10,18]$. This model actually helps us to understand and then simulate the reactions that take place in human skin and lead to the sweat production, e.g. during excessively warm periods when the body tries to maintain balance and constant temperature [13,25]. In addition, UTCI is "the air temperature of a reference environment that would cause in the human body the same UTCIFiala model's response as the genuine environment" $[14,18]$. It is also important to mention that the conditions of the reference environment used in this paper are confirmed in previously conducted research by various authors [10,13,14,18,24,25,28].

According to this model, there are 10 categories of cold and heat thermal stress, which are shown in Table I. The UTCI equation (1) is:

$$
U T C I=f\left(t . f, v, t_{m r t}\right)
$$

In this function, " $\mathrm{t}\left({ }^{\circ} \mathrm{C}\right)$ " represents air temperature, " $\mathrm{f}(\%)$ " is relative humidity, " $\mathrm{v}(\mathrm{m} / \mathrm{s})$ " is wind speed, and " $\mathrm{t}_{\mathrm{mrt}}\left({ }^{\circ} \mathrm{C}\right)$ " is mean radiant temperature. For this occasion, we additionally included another one meteorological parameter - cloudiness "N (in \% or in octants)", in order to obtain more precise calculations.

\begin{tabular}{|c|c|}
\hline \multicolumn{2}{|c|}{ UTCI thermal stress clas sification } \\
\hline UTCI $\left({ }^{\circ} \mathrm{C}\right)$ & Stress category \\
\hline UTCI $>46$ & Extreme heat stress \\
\hline $38<U T C I<46$ & Very strong heat stres 5 \\
\hline $32<U T C I<38$ & Strong hest stress \\
\hline $26<\mathrm{UTCI}<32$ & Moderate heat stress \\
\hline $9<\mathrm{UTCI}=26$ & No thermal stress \\
\hline $0<U T C I<9$ & Slight cold stress \\
\hline$-13<\mathrm{UTCI}<0$ & Moderate cold stress \\
\hline$-27<$ UTCI $<13$ & Strong cold stress \\
\hline$-40<$ UTCI $<-27$ & Very strong cold stress \\
\hline UTCI $<-40$ & Extreme cold stress \\
\hline
\end{tabular}

Table 1. UTCI thermal stress classification Source: $[13,25]$ 
Determination of a certain UTCI thermal stress was based on the meteorological data set, which was retrieved from the Republic Hydrometeorological Service of Serbia. The data set consisted of twenty Meteorological Yearbooks (from 1999 to 2018). Each Meteorological Yearbook was the source of the mean daily values of meteorological parameters $(\mathrm{t}, \mathrm{f}, \mathrm{v}, \mathrm{N})$ used in this study [29]. The mentioned data were recorded at the Meteorological Observatory Belgrade (the station is located in the area called "western Vračar"). Software Bioklima 2.6, developed by Prof. Krzysztof Błażejczyk, was used as a tool for UTCI calculations [30].

\section{RESULTS}

Abdel-Ghany et al. [11] have defined human thermal comfort "as a condition of mind, which expresses satisfaction with the surrounding environment". Additionally, they singled out high temperatures and humidity as the main reasons that cause heat stress [11]. These microclimatic indicators are those that determine outdoor thermal comfort. How people feel in the environment, has a strong impact e.g. on working performance, lifestyle, health, etc. Under the influence of intensive urbanization, morphological characteristics and other factors, the air temperature in cities is almost always higher in relation to the temperature measured in the surrounding rural areas [31]. Battista et al. [31] have estimated that for the medium-sized cities difference in air temperatures amounts between $0.5^{\circ} \mathrm{C}$ and $3^{\circ} \mathrm{C}$. This can reduce OTC, provoke health problems, and reduce the energy efficiency of buildings [5,32]. Furthermore, reduced OTC may have an indirect impact on indoor environments, interfering with indoor thermal comfort or enhancing/reducing energy loads for air conditioning $[9,10]$.

As already mentioned, Belgrad's climate belongs to the Cfa climate type (a humid subtropical climate). According to Binarti et al. [6] the humid tropical and subtropical climate covers a vast area of the globe, which is inhabited by more than $33 \%$ of the world's population. Berger [33] has noted that UHI occurs in cities belonging to this climate twice as much as cities in other climatic zones. That is the main reason why Belgrade was chosen as a study area for the research.

The research was conducted in two phases. First, authors have observed the different index values and categories of thermal stress on a daily basis, year after year. In the second part, we have analyzed separately the first (1999-2008) and second decade (2009-2018) to gain insight into what long-term changes of OTC can be expected in the future.
Figure 3, 4, and 5 show the ratio of the total number of days for each category of thermal stress during the investigated period (June - August, 1999-2018). Fig. 3 distinctly shows that in June outdoor thermal comfort is the most favorable during the summer season in Belgrade. June is the only month where the results showed the presence of the cold thermal stress. The minimum value of the index was recorded on 9th June, 2005 $\left(\mathrm{UTCI}=-3.75^{\circ} \mathrm{C}\right)$. After 2005 , cold stress during summer in Belgrade was not recorded (regarding the mean daily values of meteorological parameters that were used in this study). On a mean daily level, the prevalent category of thermal stress (during all three months) is the one where the values of UTCI are between $26^{\circ} \mathrm{C}$ and $32^{\circ} \mathrm{C}$, which means that people outdoors feel „moderate heat stress". Comparing these three months, we can also conclude that during June, the days with „no thermal stress" most often occur $(9<\mathrm{UTCI}<26)$.

At first glance, we can see that the OTC in Belgrade has been noticeably reduced, mainly in July and August (Fig. 4 and 5). It can be concluded that the weather conditions during July and August lead to unfavorable bioclimatic conditions, and as a result of that in many cases, UTCI value on a daily level belongs to the categories of "moderate" $(26<\mathrm{UTCI}<32)$ and "strong" $(32<\mathrm{UTCI}<38)$ heat stress. However, the presence of strong heat stress varied over the years, especially in August 2018, when 16 days with "strong heat stress" were recorded (of which 5 and 7 consecutive days), while in August 2002, 2004 and 2005 only 2 days were recorded (in each year). According to this category of thermal stress as adverse years 2017 (14 days), 2015 (12 days), and 2012 (12 days) also stand out.

Prolonged periods of high temperatures in July 2007, enabled the occurrence of the longest heat stress event during these 20 years, with 10 consecutive days when the daily index value was over $32^{\circ} \mathrm{C}$. In July 2007 , there were 15 such days in total. The second-longest heat stress event, with 8 consecutive days in the category of thermal stress between $32^{\circ} \mathrm{C}$ and $38^{\circ} \mathrm{C}$, occurred in July 2012. In total, in July 2012, there were 14 such days. According to the Republic Hydrometeorological Service of Serbia [29], the year 2012 was the second hottest year since 1951. What is even more interesting, since 2007, an obvious reduction in the number of days without thermal stress was registered, i.g. in 2012 and 2016 there were just 3 days in that category. In 2017, only 1 day with "no-thermal stress" was registered, while in 2018 there was no such day. 
Analyses of input data and obtained results have shown the increasing frequency of extreme summer temperatures. Also, an increase in UTCI values was noticed over a 20 -year period. As regards the thermal stress category of "very strong heat stress" (where the index value is between $38^{\circ} \mathrm{C}$ and $46^{\circ} \mathrm{C}$ ), there were five cases when UTCI has overstepped its threshold: in 2000 (UTCI $=38.3^{\circ} \mathrm{C}, 4^{\text {th }} \mathrm{July}$ ), in 2002 (UTCI $=38.17^{\circ} \mathrm{C}$, $24^{\text {th }} \mathrm{June}$ ), in 2007 (UTCI $\left.=39.38^{\circ} \mathrm{C}, 22^{\text {nd }} \mathrm{July}\right)$, in 2013 (UTCI $\left.=38.49^{\circ} \mathrm{C}, 29^{\text {th }} \mathrm{July}\right)$, and 2017 (UTCI $=38.47^{\circ} \mathrm{C}$, $5^{\text {th }}$ August). The mean daily values of UTCI were also high in 2012 and 2015 , when they almost reached $38^{\circ} \mathrm{C}$. The highest UTCI value during the whole investigated period was registered on $22^{\text {nd }}$ July $2007\left(39.38^{\circ} \mathrm{C}\right)$. As stated by Tošić et al. [22] just two days later, on $24^{\text {th }}$ July 2007 , a record temperature of $43.6^{\circ} \mathrm{C}$ was registered, which was the highest recorded temperature in Belgrade in the past 120 years.

The findings in this paper are in keeping with the other papers which have studied different phenomena connected with weather conditions. For instance, in terms of extreme weather conditions in Serbia, Unkašević and Tošić particularly singled out the heatwave that lasted from $14^{\text {th }}$ to $27^{\text {th }}$, July 2007 [34]. Unkašević et al. [21] have been investigated trends in extreme temperatures in Belgrade from 1975 to 2003 to estimate how an increase in the mean summer temperatures is linked to changes in the extreme maximum and minimum temperatures. It is believed that the rising average seasonal temperatures are connected with a significant increase in the occurrence of extreme maximum temperatures [21]. Furthermore, the findings of Unkašević et al. [21] show that the average summer temperature in Belgrade has increased by $0.1316^{\circ} \mathrm{C} / \mathrm{yr}$. As Đorđević claims [35], in observed period from 1957 to 2006 the rise of an average, maximum and minimum annual air temperature in Belgrade was significant. In addition, Tošić et al. [22] recognized the year 2012, followed by 2007, 2011, and 2017, as a year with a maximum number of fires within a period of 18 years (2000-2017). Moreover, a high possibility of fire contingency in Belgrade was present almost every year after 2007 (with the exception of 2014) [22].

Comparing two decades 1999-2008 and 2009-2018, the results showed a decline in the number of days defined as days "without thermal stress", when UTCI mean daily value was between $9^{\circ} \mathrm{C}$ and $26^{\circ} \mathrm{C}$. On the other hand, there was an increase in all other categories distinguished by a higher degree of thermal discomfort. If we look at the data obtained for August (Fig. 5), we can see that the number of days in "strong heat stress" category rose from 64 (1999-2008) to 91 (2009-2018) which means almost $30 \%$ of the increase. Simultaneously, the number of days with "no-thermal stress" $(9<\mathrm{UTCI}<26)$ in August decreased by more than $50 \%$, from 80 (1999-2008) to only 36 (2009-2018). In addition, we have registered, for the first time in these 20 years, a day with "very strong heat stress" in August, and what is more important is that it was the maximum summer value of UTCI in 2017.

We have similar results for July. For example, UTCI in "moderate" and "strong heat stress" category records a constant growing tendency - from 149 (1999-2008) to 161 (2009-2018) for moderate, and from 79 to 104 for strong heat stress (increase of 24\%). Concurrently, there was a $47 \%$ drop in the total number of days with "no-thermal stress" (from 80 to 42 such days) (Fig. 4).

Slightest changes were observed in June. The number of days with "moderate heat stress" is almost the same 157 such days in the first decade, and 158 in the second. Some changes can be noticed regarding the days without thermal stress, where a decrease was recorded (from 98 to 92). Also, in the category of strong thermal stress, an increase was registered (from 42 to 50 such days).

All of the above gives us a verification that the OTC inBelgrade has been reducing in the last 20 years.

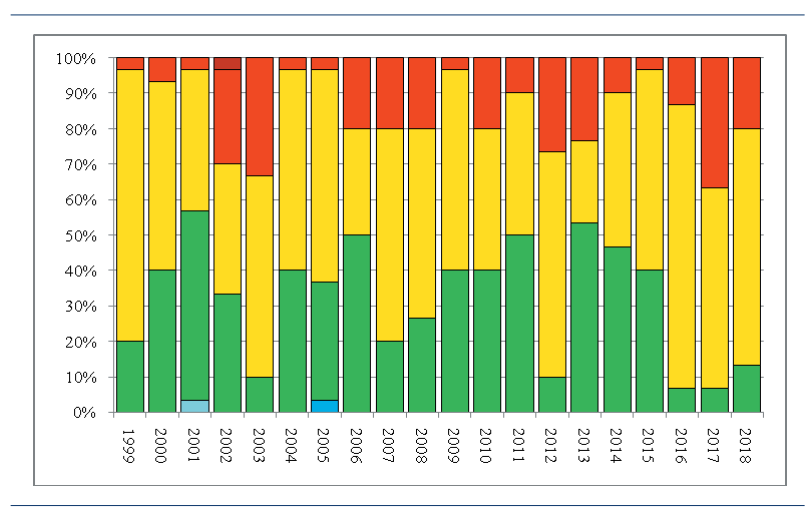

Fig. 3.UTCI thermal stress categories in total, June 1999-2018

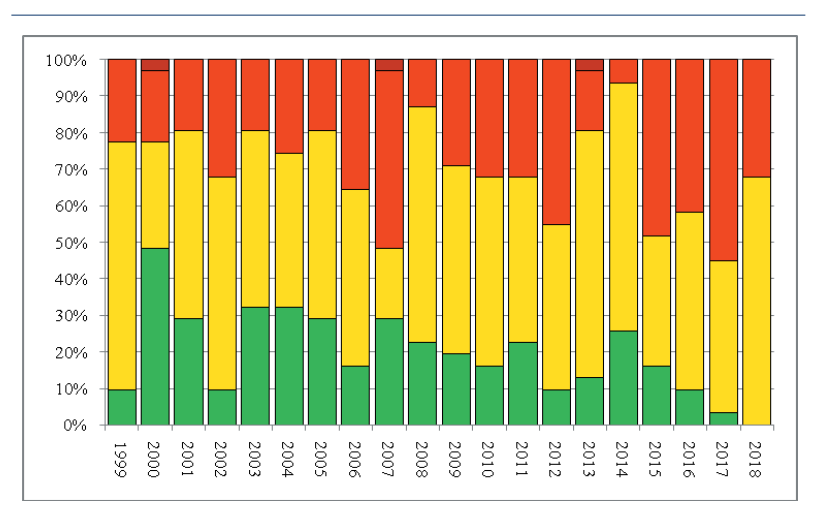

Fig. 4.UTCI thermal stress categories in total, July 1999-2018 


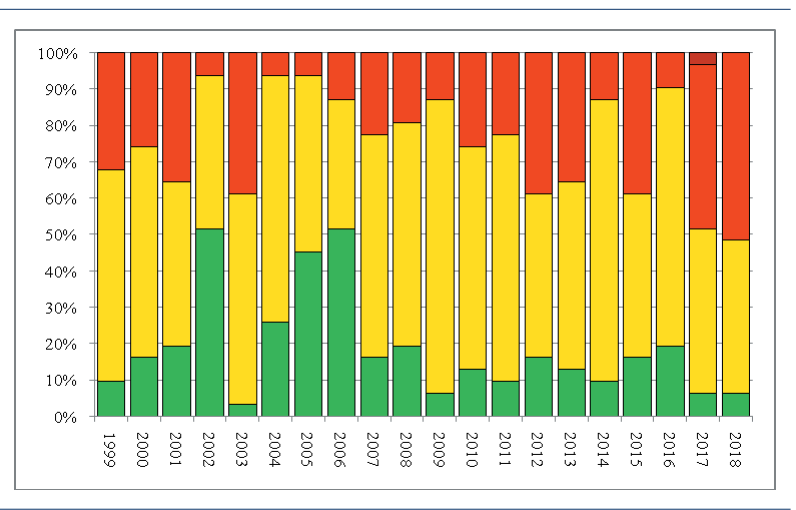

Fig. 5.UTCI thermal stress categories in total,

Aug 1999-2018

Considering that some of the most significant changes in terms of outdoor thermal comfort in Belgrade have occurred in July and August during the period from 1999 to 2018 , these two months were further analyzed. Fig. 6 and 7 show the trendline of the number of days for different categories of thermal stress according to UTCI. Table II shows the annual values of the growing or descending trend of a particular thermal stress indicator. By analyzing the obtained graphs, the following can be concluded: the crucial changes of OTC in Belgrade are connected to the "no-thermal stress" and "strong heat stress" categories. The green trendline shows a constant decline in the number of days without thermal stress from 1999 to 2018, with an annual trend of -0.36 days/yr in July, and -0.272 days/yr in August. On the other hand, the highest growth trend was recorded in July in the "strong heat stress" category (red trendline), amounting to 0.275 days/yr. August follows, with a growth trend of 0.229 days/yr. During August, the category "very strong heat stress" manifests a slight growing tendency (0.012 days/yr), which confirms that the bioclimatic conditions in Belgrade are subject to change, leading to more uncomfortable OTC.

\begin{tabular}{|c|c|c|}
\hline Heat stress category & July & August \\
\hline No thermal & -0.36 & -0.272 \\
\hline Moderate & 0.067 & 0.03 \\
\hline Strong & 0.275 & 0.229 \\
\hline Very strong & -0.008 & 0.012 \\
\hline
\end{tabular}

Table 2. Annual values of the growing or descending trend of a particular thermal stress indicator, Belgrade, July and August

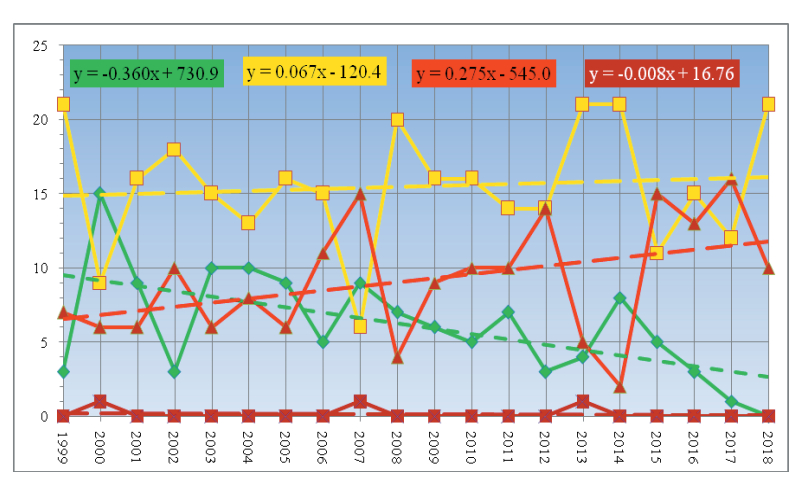

Fig. 6. Trendline - number of days for each thermal stress category of UTCI, Belgrade, July 1999-2018

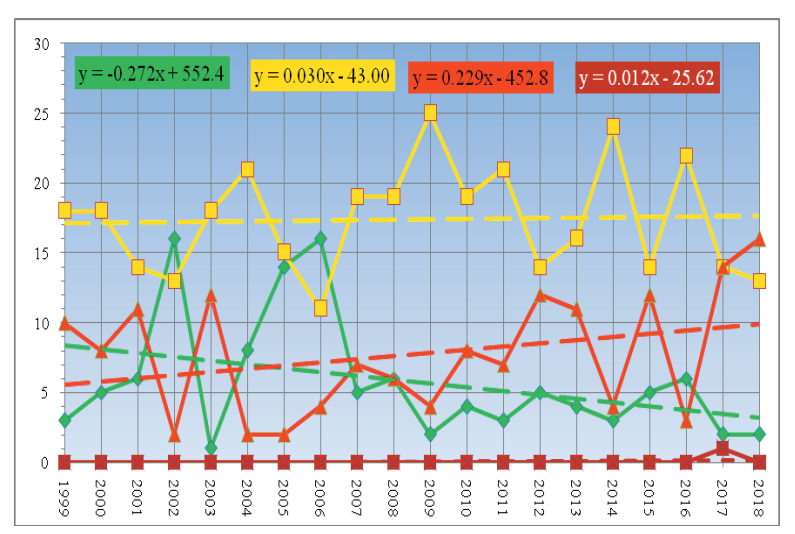

Fig. 7. Trendline - number of days for each thermal stress category of UTCI, Belgrade, August 1999-2018

\section{CONCLUSION}

The primary aim of this study was to evaluate the OTC of the central urban zone of Belgrade during the hottest summer months. Outdoor thermal comfort assessment, for the period from 2009 to 2018, was conducted by using UTCI, a heat budget index, which represents the heat stress of the human organism caused by meteorological conditions. The obtained results enable better insight and understanding of how climate change affects local bioclimatic conditions in urban areas. We can also see how outdoor thermal comfort in Belgrade becomes more and more unpleasant, year after year, especially after 2007.

The increasing temperature (annual and mean daily) and extreme summer temperatures, prolonged heatwave periods, Belgrade's UHI phenomenon, aerosols, air pollution (cause of the greenhouse effect), lack of "green architecture" and open green spaces in the central part of the city, high urbanization and other anthropogenic impacts lead to reducing of OTC. All of this has a strong 
and negative impact on the human organism, public health and the quality of life in Belgrade. OTC causes discomfort predominantly during July and August. In the twenty-year period, 2007, 2012, 2015, 2017, and 2018 stands out as the most adverse ones. The year $2007 \mathrm{can}$ be marked as a "turning point", because after this year days without thermal stress are in permanent decrease, with an annual trend of -0.36 days/yr in July, and -0.272 days/yr in August, while the number of days that belongs to other categories of heat stress is on the rise. The highest growth trend of 0.275 days/yr was observed in July. The maximum index value during the investigated period was $39.38^{\circ} \mathrm{C}\left(22^{\text {nd }} J u l y 2007\right)$, while the minimum value was $-3.75^{\circ} \mathrm{C}$ ( $9^{\text {th }}$ June, 2005). That was an isolated case of "moderate cold stress", and after 2005, cold stress during summer in Belgrade was not recorded.

\section{ACKNOWLEDGMENT}

This paper represents the research outcome of the National Project (No. 176008), funded by the Ministry of Education, Science and Technological Development of Serbia, and according to the Agreement of Cooperation No. 0801-417/1 (21/03/2019).

\section{REFERENCES}

[1] A.M. Tomczyk, and M. Owczarek, "Occurrence of strong and very strong heat stress in Poland and its circulation conditions", Theor. Appl. Climatol., vol. 139, pp. 893-905, 2020.

[2] ANSI/ASHARE Standard 55: Thermal Environmental Conditions for Human Occpancy, ANSI/ASHRAE Approved, available at: http://www.techstreet.com/ ashrae/standards (last access: 21 ${ }^{\text {st }}$ April 2020), 2017.

[3] J. Geletič, M. Lehnert, P. Dobrovolný, and M. Žuvela-Aloise, "Spatial modelling of summer climate indices based on local climate zones: expected changes in the future climate of Brno, Czech Republic". Clim. Chang., vol. 152 (3-4), pp. 487-502, 2019

[4] J. Geletič, M. Lehnert, and M. Jurek, "Spatiotemporal variability of air temperature during a heat wave in real and modified landcover conditions: Prague and Brno (Czech Republic)", Urban Climate, vol. 31, pp. 100588, 2020.

[5] R. Aghamolaei, M. Mehdi Azizia, B. Aminzadeha, and P.A. Mirzaei, "A tempo-spatial modelling framework to assess outdoor thermal comfort of complex urban neighbourhoods", Urban Climate, vol. 33, pp. 100665, 2020.
[6] F. Binarti, M.D. Koerniawan, S. Triyadi, S.S. Utami, and A. Matzarakis, "A review of outdoor thermal comfort indices and neutral ranges for hot-humid regions", Urban Climate, vol. 31, pp. 100531, 2020.

[7] C.K.C. Lam, and K.K. Lau, "Effect of long-term acclimatization on summer thermal comfort in outdoor spaces: a comparative study between Melbourne and Hong Kong", Int J Biometeorol., vol. 62, pp. 1311-1324, 2018.

[8] L. Kolendowicz, M. Półrolniczak, K. Szyga-Pluta, and E. Bednorz, "Human-biometeorological conditions in the southern Baltic coast based on the Universal Thermal Climate Index (UTCI), Theor Appl Climatol., vol. 134, pp. 363-379, 2018.

[9] P. Bröde, E.L. Krüger, F.A. Rossi, and D. Fiala, "Predicting urban outdoor thermal comfort by the Universal Thermal Climate Index UTCI - a case study in Southern Brazil”, Int J Biometeorol, vol. 56 (3), pp. 471-480, 2012.

[10] P. Bröde, E.L. Krüger, and D. Fiala, "UTCI: validation and practical application to the assessment of urban outdoor thermal comfort", Geographia Polonica, vol. 86, pp. 11-20, 2013.

[11] A.M. Abdel-Ghany, I.M. Al-Helal, and M.R. Shady, "Human Thermal Comfort and Heat Stress in an Outdoor Urban Arid Environment: A Case Study", Advances in Meteorology, 2013.

[12] N. Mölders, "Outdoor Universal Thermal Comfort Index Climatology for Alaska”, Atmospheric and Climate Sciences, vol. 9, pp. 558-582, 2019.

[13] K. Błazejczyk, M. Kuchcik, A. Błazejczyk, P. Milewski, and J. Szmyd, "Assessment of urban thermal stress by UTCI - experimental and modelling studies: an example from Poland", ERDE, vol. 145, pp. 16-33, 2014.

[14] C. Di Napoli, F. Pappenberg, and H.L. Cloke, "Assessing heat-related health risk in Europe via the Universal Thermal Climate Index (UTCI)", Int. J. Biometeorol., vol. 62, pp. 1155-1165, 2018.

[15] J. Dunjić, "Outdoor Thermal Comfort Research in Urban Areas of Central and Southeast Europe: A Review", Geographica Pannonica, vol. 23 (4), pp. 359-373, 2019.

[16] K. Pantavou, G. Theoharatos, M. Santamouris, and D. Asimakopoulos, "Outdoor thermal sensation of pedestrians in a Mediterranean climate and a comparison with UTCI", Building and Environment, vol. 66, pp. 82-95, 2013.

[17] M. Pecelj, A. Đordđević, M.R. Pecelj, J. PeceljPurković, D. Filipović, and V. Šećerov, "Biothermal conditions on Mt. Zlatibor based on thermophysiological indices", Archives of biological sciences, vol. 69 (3), pp. 455-461, 2017. 
[18] M. Pecelj, M. Lukić, D. Filipović, B. Protić, and U. Bogdanović, "Analysis of the Universal Thermal Climate Index during heat waves in Serbia”, Nat. Hazards Earth Syst. Sci., vol. 20, pp. 2021-2036, 2020.

[19] M. Lukić, "An analysis of the influence of air temperature and humidity on outdoor thermal comfort in Belgrade (Serbia) using a simple heat index", Archives for Technical Sciences, vol. 21 (1), pp. 75-84, 2019.

[20] B. Basarin, T. Lukić, and A.

"Matzarakis,Quantification and assessment of heat and cold waves in Novi Sad, Northern Serbia", Int. J. Biometeorol., vol. 60 (1), 139-150, 2016.

[21] M. Unkašević, D. Vujović, and I. Tošić, “Trends in extreme summer temperatures at Belgrade", Theor. Appl. Climatol., vol. 82, pp. 199-205, 2005.

[22] I. Tošić, D. Mladjan, M. B. Gavrilov, S. Živanović, M. G. Radaković, S. Putniković, P. Petrović, I. Krstić Mistridželović, and S. B. Marković, "Potential influence of meteorological variables on forest fire risk in Serbia during the period 2000-2017", Open Geosci., vol. 11, pp. 414-425, 2019.

[23] Statistical Office of the Republic of Serbia: Profile of the municipality of Vračar, available at: http://devinfo.stat.gov.rs/SerbiaProfileLauncher/files/profiles/ sr/1/DI_Profil_Vracar_EURSRB001001001003.pdf (last access: $9^{\text {th }}$ August 2020), 2020.

[24] G. Jendritzky, R. De Dear, and G. Havenith, "UTCI - Why another thermal index?", Int. J. Biometeorol., vol. 56, pp. 421-428, 2012.

[25] K. Blazejczyk, G. Jendritzky, P. Bröde, D. Fiala, G. Havenith, Y. Epstein, A. Psikuta, and B. Kampmann, "An introduction to the Universal Thermal Climate Index”, Geogr. Pol., vol. 86, pp. 5-10, 2013.

[26] ISO 8996: Ergonomics of the thermal environment - Determination of metabolic rate, available at: https://www.iso.org/standard/34251.html (last access: $2^{\text {nd }}$ April 2020), 2004.

[27] D. Fiala, G. Havenith, P. Bröde, B. Kampmann, and G. Jendritzky, "UTCI-Fiala multi-node model of human heat transfer and temperature regulation", Int. J. Biometeorol., vol. 56, pp. 429-441, 2012.

[28] P. Bröde, D. Fiala, K. Błazejczyk, I. Holmér, G. Jendritzki, B. Kampmann, B. Tinz, and G. Havenith, "Deriving the operational procedure for the Universal Thermal Climte Index (UTCI), Int. J. Biometeorol., vol. 56, pp. 481-494, 2012.

[29] Republic Hydrometeorological Service of Serbia: Meteorological Yearbook for the period from 1998 to 2017, available at: http://www.hidmet.gov.rs/ latin/meteorologija/klimatologija_godisnjaci.php, (last access: $15^{\text {th }}$ May 2020).

[30] Institute of Geography and Spatial Organization, Polish Academy of Science: BioKlima 2.6 - Universal tool for bioclimatic and thermophysiological studies, available at: https://www.igipz.pan.pl/ Bioklima-zgik.html (last access: $10^{\text {th }}$ August 2020).
[31] G. Battistaa, R. De Lieto Vollaroa, and M. Zinzib, "Assessment of urban overheating mitigation strategies in a square in Rome, Italy", Solar Energy vol. 180, pp. 608-621, 2019.

[32] R. Aghamolaei, M.H. Shamsi, M. Tahsildoost, J. O’Donnell, “ Review of district-scale energy performance analysis: outlooks towards holistic urban frameworks", Sustain. Cities Soc., vol. 41, pp. 252 264, 2018.

[33] M. Berger, "Urban heat-balling: a review of measures on reducing heat in tropical and subtropical cities”, In: Sheng, T., Hing, P. (Eds.), Sustainable Future Energy 2012: International Energy Conference, Brunei Darussalam \& $10^{\text {th }}$ Sustainable Energy and Environment (SEE) Forum Proceeding. Universiti Brunei Darussalam, Brunei Darussalam, pp. 445-451, 2012.

[34] M. Unkašević, and I. Tošić, “The maximum temperatures and heat waves in Serbia during the summer of 2007", Climate Change, vol. 108 (1-2), pp. 207-223, 2011.

[35] S. Đorđević, “Temperature and Precipitation Trends in Belgrade and Indicators of Changing Extremes for Serbia”, Geographica Pannonica, vol. 12 (2), pp. 62-68, 2008. 